\title{
Evaluation of Hydraulic Characteristics of the Normal Fault Based on Key Data
}

\author{
Qi Wang ${ }^{1}$, Xinyi Wang ${ }^{*}, 2,3$, Xiaoman $\mathrm{Liu}^{2}$, Hongying $\mathrm{Ji}^{2}$ and Quanlin $\mathrm{Hou}^{1}$ \\ ${ }^{1}$ College of Earth Science, University of Chinese Academy of Sciences, Beijing, 100049, China \\ ${ }^{2}$ Institute of Resources and Environment, Henan Polytechnic University, Jiaozuo, 454000, China \\ ${ }^{3}$ Collaborative Innovation Center of Coalbed Methane and Shale Gas for Central Plains Economic Region of Henan \\ Province, Jiaozuo, 454000, China
}

\begin{abstract}
Based on the data of geological drill holes, roadway drifting, transient electromagnetic exploration, mine water inrushes, hydro-geochemistry and water levels on each side of the Haotang Normal Fault, This paper studied the waterbearing capacity and water conductivity of the fault in the Pingdingshan Tian'an Mining Company Limited No. 7 Coal Mine. The results indicate that the Haotang Fault is subject to compressive or shear-compressive stresses. The waterbearing capacity and water conductivity of the fault is poor. The water content of the Cambrian limestone in footwall is higher than that in hanging wall, and the mining threat of $1_{5}$ coal seam in the south district(footwall) is greater than that in the north district(hanging wall).
\end{abstract}

Keywords: High-angle normal fault, hydraulic characteristics, mine water inrush, water conductivity, water content.

\section{INTRODUCTION}

Coal mine water inrush accidents are closely related to the complexity of geological conditions [1-3]. The depth of overburden and the stratigraphical relationships are usually varied and complex, particularly near the fault. This not only seriously affects the efficiency and safety of mining, but leads to significant changes in mine-water in flow. Therefore, a study of the spatial structure and hydraulic characteristics of the fault was conducted to identify changes in the flow of water into the mine and prevent water inrush.

The structure and hydraulic characteristics of the fault are predominantly studied using geological methods, hydrogeological methods, hydrogeochemical methods, geophysical prospecting, etc. However, because the spatial structure and hydraulic characteristics are affected by many factors, in practice only one or two methods are used [4-14].

In this study, using data of geological drillholes, roadway drifting, transient electromagnetic exploration (TEM), mine water inrush history, hydro-geochemistry, and the water levels on both sides of the Haotang Normal Fault [15-17], the water yield properties and water conductivity of the fault are analyzed, and their influences in the process of $1_{5}$ coal seam mining are investigated.

\section{LOCATION AND QUIFERS}

The Pingdingshan Tian'an Mining Company Limited No.7 Coal Mine (No.7 Mine) is located at the north-west of

*Address correspondence to this author at the Henan Polytechnic University, New \& Hi-Tech Zone, Jiaozuo, Henan, China;

Tel: +86-18539159073; Fax: +86-0391-3987075; Email: wangxy@hpu.edu.cn the city of Pingdingshan, China, at $33^{\circ} 44^{\prime} 30^{\prime \prime}-33^{\circ} 45^{\prime} 25^{\prime \prime} \mathrm{N}$, $113^{\circ} 13^{\prime} 31.5^{\prime \prime}-113^{\circ} 16^{\prime} 56.5^{\prime \prime} \mathrm{E}$.

The mine is approximately $5.2 \mathrm{~km}$ long from east to west, and $1.6 \mathrm{~km}$ wide from north to south, covering an area of about $8.3 \mathrm{~km}^{2}$. It is divided into north district and south district by the Haotang Fault (Fig. 1). The No. 7 Mine produces coal from the $1_{5}$ coal seam at the base of the Carboniferous Pennsylvanian Formation (Fig. 2). The buried depth of $1_{5}$ coal at south and north district are 86-400 $\mathrm{m}$ and 400-523 m.

As shown in Fig. (2), the immediate roof aquifer of the $1_{5}$ coal is the $\mathrm{L}_{5}$ limestone of the Carboniferous Taiyuan Formation. The immediate floor aquifer is the $\mathrm{L}_{6+7}$ limestone aquifer overlying the Cambrian limestone aquifer (CL). The $\mathrm{L}_{5}$ limestone aquifer is thin (with the average thickness of $4.5 \mathrm{~m}$ ), and is only weakly recharged with water, so its threat to the mining of $1_{5}$ coal is relatively small.

The $\mathrm{L}_{6+7}$ limestone aquifer is thin (with the average thickness of $5 \mathrm{~m}$ ), and the underlying aluminum mudstone has an average thickness of $3 \mathrm{~m}$ (with the minimum thickness $0.4 \mathrm{~m}$ ). The CL aquifer is more than $300 \mathrm{~m}$ thick [18]. It is a confined aquifer and has a extremely uneven water yield. Because these are closely connected hydraulically and the water levels aquifer are generally identical in the $\mathrm{L}_{6+7}$ and the CL, both of the $\mathrm{L}_{6+7}$ and CL pose severe threat to mining the $1_{5}$ coal.

In the south district of the No. 7 Mine, the CL groundwater is recharged by atmospheric precipitation and river at the emergence zone of the CL (Fig. 1).

Since the recharged area is large and the flow distance is shorter in the CL groundwater, and the normal mine water 


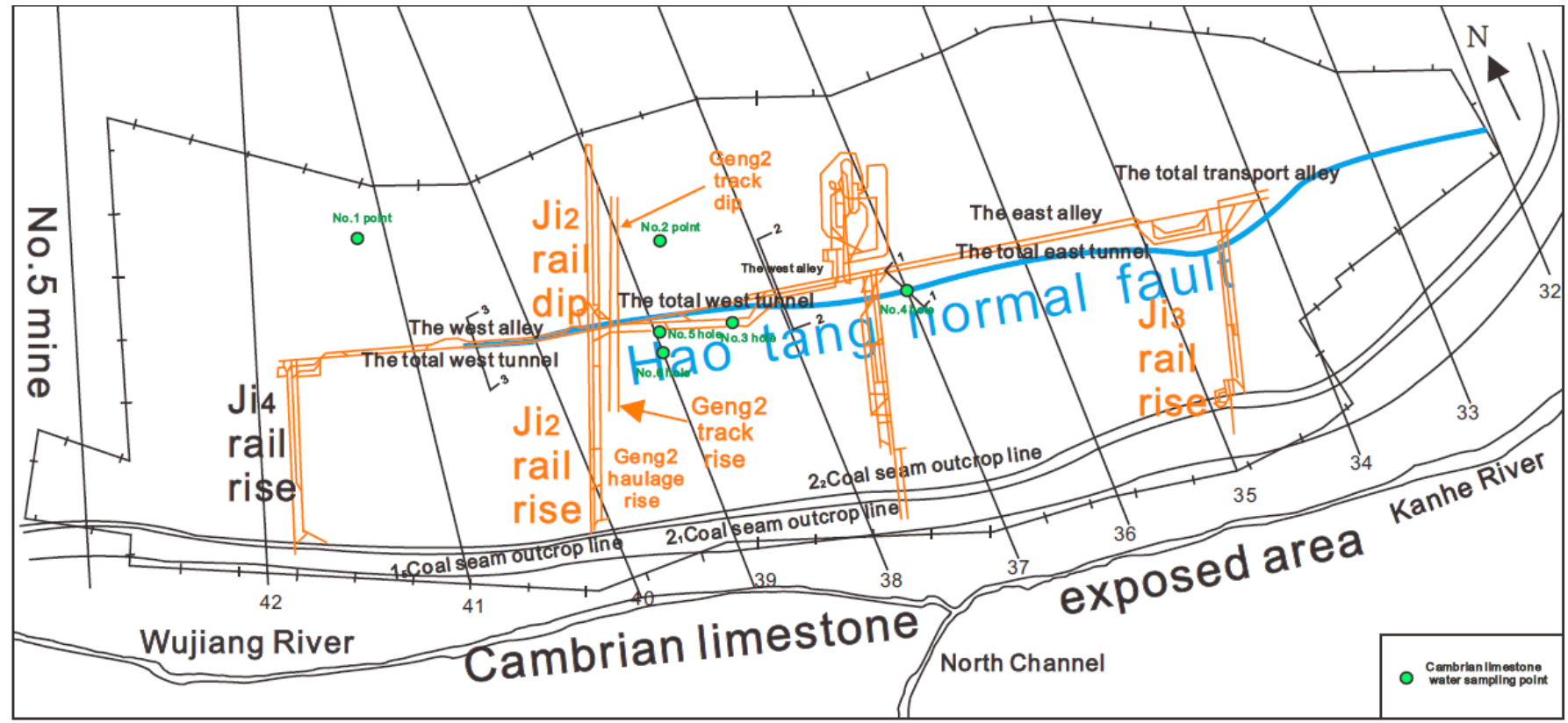

Fig. (1). Map of the No. 7 Mine showing the location of the Haotang Fault.

\begin{tabular}{|c|c|c|c|c|}
\hline System & Formation & Poles thickness & Lithologic column & Coal seam \\
\hline \multirow{6}{*}{ 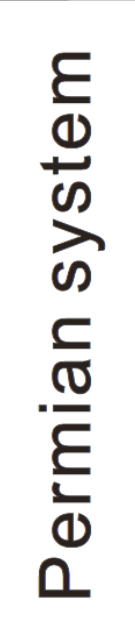 } & \multirow{6}{*}{ 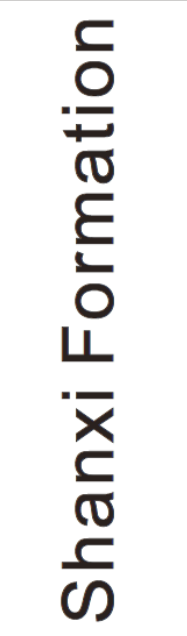 } & 12.90 & $(=)$ & \multirow{2}{*}{\begin{tabular}{|c}
$\begin{array}{c}\text { sign layer } \\
\text { Purple mudstone }\end{array}$ \\
$\begin{array}{c}\text { K16 Fragrant } \\
\text { charcoal sandstone }\end{array}$
\end{tabular}} \\
\hline & & 5.00 & $\frac{\| D^{\prime}}{--}$ & \\
\hline & & 4.85 & \multirow{2}{*}{ ID } & $\begin{array}{l}\text { K17 Dazhan } \\
\text { sandstone }\end{array}$ \\
\hline & & 1.20 & & 22 Coal \\
\hline & & 3.85 & & 21 Coal \\
\hline & & 6.75 & $\ddot{*}$ & K19 Mudstone \\
\hline \multirow{5}{*}{ 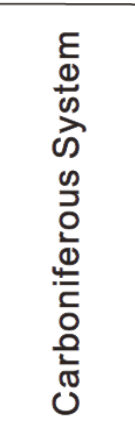 } & \multirow{3}{*}{ 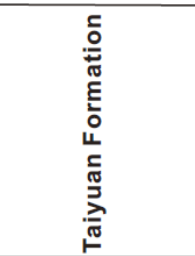 } & 4.00 & 1 & L1 Limestone \\
\hline & & 4.50 & & L5 Limestone \\
\hline & & 1.55 & & 15 Coal \\
\hline & \multirow[t]{2}{*}{$\bar{\delta}$} & 6.75 & 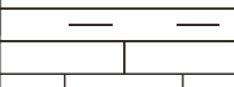 & L6+7 Limestone \\
\hline & & $\begin{array}{l}5.00 \\
5.00\end{array}$ & - $\diamond$ & $\mathrm{K}_{21}$ Purple mudstone \\
\hline 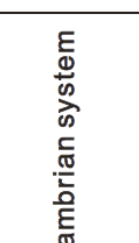 & 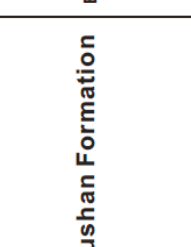 & \multirow[t]{2}{*}{68.00} & & \multirow[t]{2}{*}{$\begin{array}{l}\text { Cambrian } \\
\text { limestone }\end{array}$} \\
\hline రూ & 0 & & & \\
\hline
\end{tabular}

Fig. (2). Columnar schematic diagram of the coal seam overlying the Cambrian limestone. Source: [15]. 
inflow is $2197 \mathrm{~m} 3 / \mathrm{h}$ in the south district, which could be as high as $4750 \mathrm{~m} 3 / \mathrm{h}$. In the north district of the No. 7 Mine, the CL aquifer is far from the recharged area and cut by the Haotang Fault, which made the normal mine water inflow depend on the water yield properties and the hydraulic conductivity of the Haotang fault. The present study on the hydraulic characteristics of the Haotang Fault would be significant for establishing technical safety measures for mining in the 15 coal.

\section{FAULT DESCRIPTION AND WATER YIELD PROPERTIES}

\subsection{Fault Description}

The Haotang Fault is concealed below the surface for about $200 \mathrm{~m}$, along the east-west of No. 7 Mine (Fig. 1). It is a normal dip-slip fault striking at $120^{\circ}$ and plunging at $30^{\circ}$. Its dip angle is $40-60^{\circ}$, with $10-35 \mathrm{~m}$ vertical displacement. The southern block of the fault has been uplifted relative to the northern block.

Fig. (3) shows three typical north-south cross-sections of the coal measures and aquifer, with the locations of the Haotang Fault and other minor faults. In section 1-1, the CL in the north and south districts are seen to be directly linked. Section 2-2 shows that the CL in the south district is directly connected to the $1_{5}$ coal. Section 3-3 illustrated the connection between $\mathrm{CL}$ and the $\mathrm{L}_{6+7}$ limestone in north district. The distinct strata connections at the different locations illustrate the complex influence of the fault on the various strata.

\subsection{Fault Water Yield}

\subsubsection{Drilling and Roadway Engineering Details}

Six drillholes (40-23, 39-20, 37-19, 35-29, 34-22 and 3325 ) and nine roadway engineering sites in the $\mathrm{Ji}_{1}, \mathrm{Ji}_{2}$, and $\mathrm{Ji}_{3}$ mining areas intersect the Haotang Fault. The fracture plane become undulated graudally along the trend. Scars and steps oblique distributed on hanging wall. Observation and analysis of the mechanical properties at these sites have shown that the fault is subjected to compressive or shearcompressive stresses.

Drilling and roadway engineering records show that the CL karst fissures are poorly developed in the hanging wall, the footwall, and the fractures in the Haotang Fault. No water was observed from any of the drill holes nor at any of the roadway drifting project sites intersecting the fault, illustrating the low water conductivity of the fault.

\subsubsection{TEM Mothed}

To survey the water yield properties of the fault, we carried out floor TEM on lines parallel to the fault along the western roadway. The No. 3 detecting line was $780 \mathrm{~m}$ long, beginning from the north of the Haotang Fault, passing through the fault to the southern side, then turning north westward and finally reentering the fault zone (Fig. 4).

Fig. (5) (see the next page) is a cross-sectional diagram of the floor TEM results on detecting line No. 3. Clearly, the apparent resistivity was higher at $220-250 \mathrm{~m}$, where the detecting line cut across the Haotang Fault and was highest at the finishing point $(760-780 \mathrm{~m})$ in the fault zone. Normally, higher apparent resistivity indicates poorly developed limestone karst fissures and associated low water yield. This is a further evidence that the water yield of the Haotang Fault is weak.

\section{FAULT WATER CONDUCTIVITY}

The water conductivity of the Haotang Fault was comprehensively and accurately determined from the water inrush when excavating the $1_{5}$ coal, the chemical characteristics of the water in the $\mathrm{CL}$, and the water level distribution, and the TEM results.

\subsection{Water Inrush Situation}

The working face $(22090,22050,22060,22040)$ in the $1_{5}$ coal was located near the Haotang Fault in the south district. The Geng 2 haulage dip and track dip are located in the north district. The statistics for the frequency and volume of the mine water inrushes in 2002-2010 show that they occurred 53 times in the south district (34 times from the floor and 19 times from the roof; see Table 1). No inrushes occurred in the north district, where the total water inflow did not exceed $10 \mathrm{~m}^{3} / \mathrm{h}$ during roadway driveage, and the flow from the roof was only $1 \mathrm{~m}^{3} / \mathrm{h}$. Clearly, floor water in the south district seriously threatens mining in the $1_{5}$ coal, and the significant differences of floor water yield in north and south of the fault are obvious.

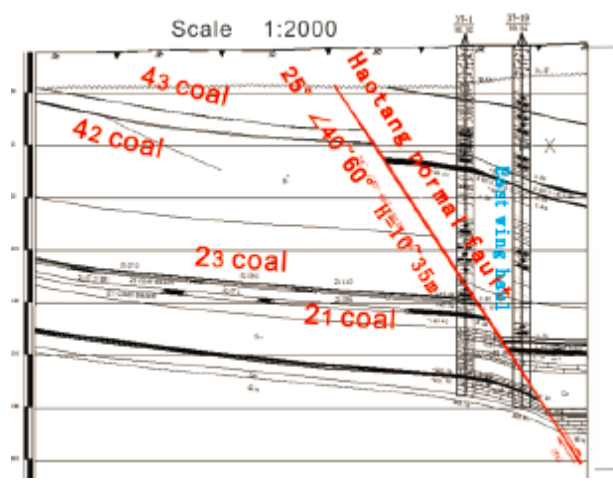

(a) section 1-1

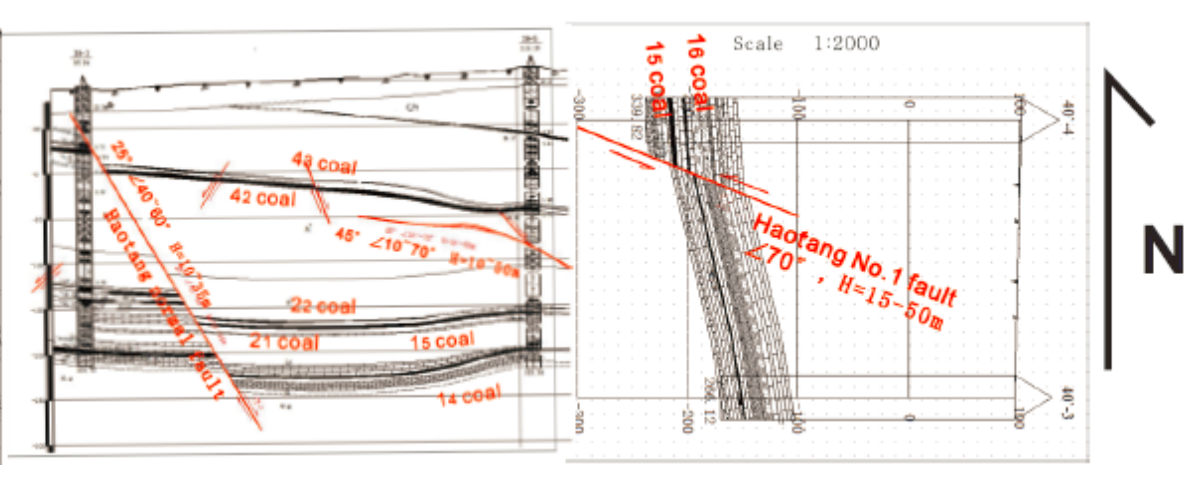

(b) section 2-2 (c) section 3-3

Fig. (3). Cross-sections through the haotang fault. Source: [15]. 


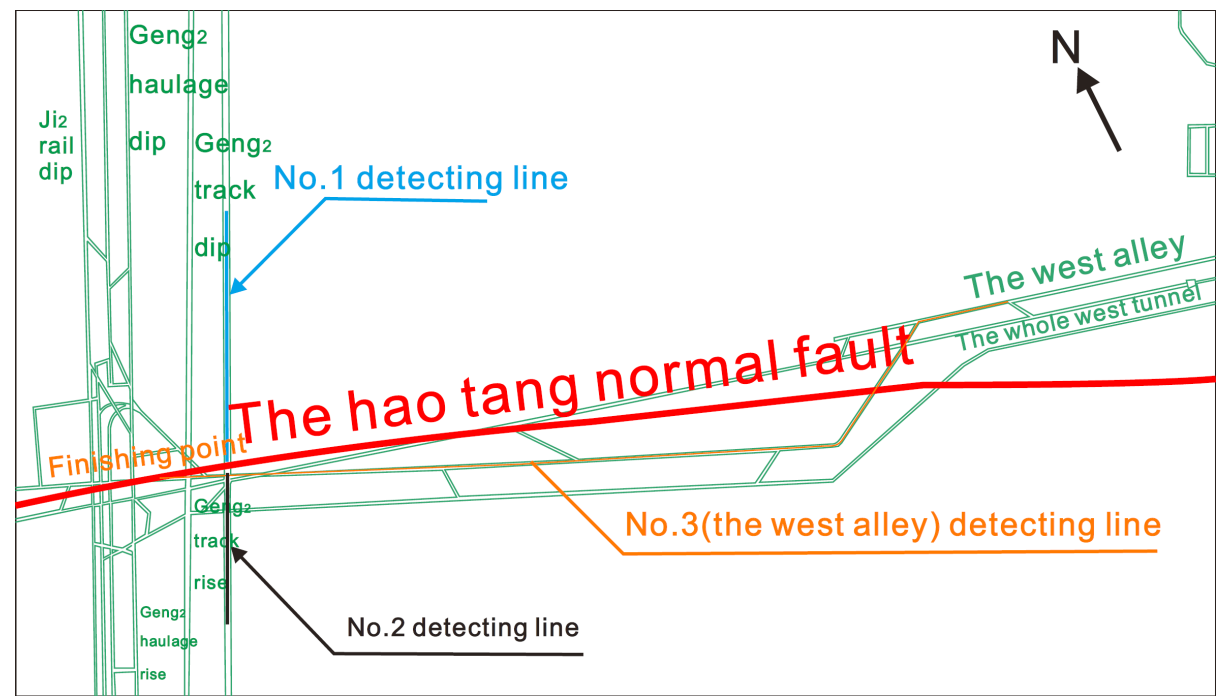

Fig. (4). Map of the TEM detecting line position. Source: [15].

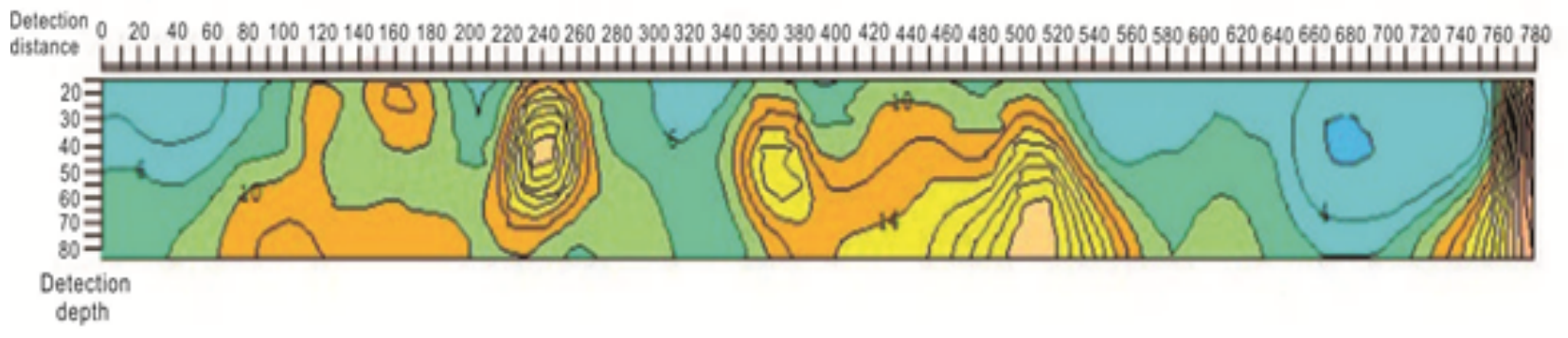

Fig. (5). Diagram of the floor TEM apparent resistivity section of the No. 3 line. Source: [15].

Table 1. Water inrush data south of the fault.

\begin{tabular}{|c|c|c|c|c|}
\hline \multirow{2}{*}{ Type } & \multirow{2}{*}{ Times } & \multicolumn{2}{|c|}{ Quantity of water inrush } & \multirow{2}{*}{ Remarks } \\
\cline { 3 - 4 } & & $\operatorname{Max}\left(\mathbf{m}^{3} / \mathbf{h}\right)$ & Average $\left(\mathbf{m}^{3} / \mathbf{h}\right)$ & \\
\hline \hline Floor & $\mathbf{3 4}$ & $\mathbf{1 3 5 0}$ & $\mathbf{7 8 . 6}$ & $\begin{array}{l}\text { The immediate floor aquifer of the } 1_{5} \text { coal is } \mathrm{L}_{6+7} \text { aquifer. When the } \mathrm{L}_{6+7} \text { linked up with the CL, water } \\
\text { inrushes were fierce of large volume and long duration, and were a significant threat to } 1_{5} \text { coal mining. }\end{array}$ \\
\hline Roof & 19 & 450 & 23.6 & $\begin{array}{l}\text { The immediate roof aquifer of the } 1_{5} \text { coal is the } \mathrm{L}_{5} \text { aquifer with small thickness and weak supply, it } \\
\text { posed a smaller threat to } 1_{5} \text { coal mining. }\end{array}$ \\
\hline
\end{tabular}

\subsection{Hydro-Geochemical Characteristics}

Six underground water samples of the CL were collected from both sides of the Haotang Fault in August 2012 (Fig. 1). Sampling point 1 and 2 (No.1 point and No.2 point) were in the north district, the others were in the south district. The proportions of $\mathrm{K}^{+}+\mathrm{Na}^{+}, \mathrm{Ca}^{2+}, \mathrm{Mg}^{2+}, \mathrm{Cl}^{-}, \mathrm{SO}_{4}{ }^{2-}$, and $\mathrm{HCO}_{3}{ }^{-}$ ions, total dissolved solids and $\mathrm{pH}$ are listed in Table 2.

As shown in Table 2, north of the Haotang Fault, the proportions of ions were basically the same on sampling points 1 and 2, which indicates a single groundwater recharge path in the CL aquifer. South of the Haotang Fault, the proportions of ions were considerably different at different sampling points, which implies that the groundwater recharge path in the southern CL aquifer is complex and is strongly affected by various water sources.

The chemical constituent are totally different on both sides of the Haotang Fault, as seen in Table 2. Therefore, we inferred that the hydraulic connection between the north and south sides of the fault is particularly weak.

\subsection{Water Level Distribution in the Aquifer}

The water level in the CL was measured in September 2012. The observed values are shown in Fig. (6) as CL water table isolines on the southern side of the Haotang Fault. It can be seen that the water table level is the lowest in the 
Table 2. CL water quality test results $(\mathrm{mg} / \mathrm{L})$.

\begin{tabular}{|c|c|c|c|c|c|c|c|c|c|}
\hline District & Number & $\mathbf{K}^{+}+\mathrm{Na}^{+}$ & $\mathrm{Ca}^{2+}$ & $\mathbf{M g}^{2+}$ & $\mathrm{Cl}^{-}$ & $\mathrm{SO}_{4}{ }^{2-}$ & $\mathrm{HCO}_{3}^{-}$ & Total Dissolved Solids & pH \\
\hline \multirow{3}{*}{ North } & 1 & 37.7 & 85.0 & 39.4 & 36.5 & 89.8 & 379.5 & 478.2 & 7.4 \\
\hline & 2 & 36.3 & 77.6 & 37.9 & 36.5 & 65.8 & 376.5 & 442.4 & 7.3 \\
\hline & Average & 37.0 & 81.3 & 38.7 & 36.5 & 77.8 & 378.0 & 460.3 & 7.4 \\
\hline \multirow{5}{*}{ South } & 3 & 20.9 & 100.0 & 9.1 & 17.4 & 120.1 & 223.1 & 379.0 & 7.7 \\
\hline & 4 & 58.4 & 72.5 & 42.4 & 50.0 & 101.8 & 373.4 & 511.9 & 7.3 \\
\hline & 5 & 32.2 & 122.4 & 25.8 & 30.1 & 167.6 & 311.8 & 534.4 & 7.3 \\
\hline & 6 & 20.7 & 85.0 & 31.8 & 29.1 & 41.8 & 370.4 & 393.6 & 7.3 \\
\hline & Average & 33.1 & 95.0 & 27.3 & 31.7 & 107.8 & 320.0 & 454.7 & 7.4 \\
\hline
\end{tabular}

south of the Haotang Fault, and increases with increasing distance southward. This indicates that, in the region of the No. 7 Mine, the aquifer is recharged by water entering at the southern outcrop of the CL.

On the northern side of the Haotang fault, the water levels are significantly different. The water table is the highest in the eastern area of the mine. This indicates that the water content of the CL aquifer is heterogeneous, and the hydraulic connection is weak.

The water levels are markedly different on either side of the Haotang Fault, and the isogram is discontinuous, confirming the poor water conductivity of the fault.

\subsection{TEM Method}

Two floor TEM exploration lines perpendicular to the fault were established on the $\mathrm{Geng}_{2}$ track (Fig. 4). Line 1(320 m long) was on the northern side of the Haotang Fault, and line 2(180 $\mathrm{m}$ long) was on the southern side of the fault.

\subsubsection{Line 1}

Fig. (7) is the cross-sectional diagram of the vertical floor TEM on line 1 . Apparent resistivity values less than $3 \Omega \cdot \mathrm{m}$ occurred in anomalous low-resistivity zones; the lowest apparent resistivity values were located at the Geng ${ }_{2}$ track dip roadway of 185-210 $\mathrm{m}$ and 260-285 m, and at depths of 55-105 $\mathrm{m}$ and 55-115 $\mathrm{m}$. The rocks near the low resistivity zones are fractured karst or high water-content zones. None of the anomalies in the low-resistivity zone gave apparent resistivity readings less than $2 \Omega \cdot \mathrm{m}$, signifying the relatively small water-bearing capacity of the overall CL aquifer on the northern side of the Haotang Fault.

\subsubsection{Line 2}

At the time of the readings on line 2, interference was small and the background apparent resistivity was as high as $54 \Omega \cdot \mathrm{m}$. Values below $10 \Omega \cdot \mathrm{m}$ occurred only in relatively anomalous low-resistivity zones. Fig. (8) is a cross-sectional chart of the floor TEM results, showing the locations of the lower apparent resistivity values at the Geng $_{2}$ track rise roadway of 18-40 $\mathrm{m}$ and $84-180 \mathrm{~m}$, and at depths of $30-90 \mathrm{~m}$ and 24-90 $\mathrm{m}$. Zones of apparent resistivity less than $2 \Omega \cdot \mathrm{m}$ in the south of the Haotang Fault are corresponded to the presence of well-developed karst fissuring in the CL, from which we inferred that the anomalous low-resistivity zones indicated large volumes of water stored in the strata. Subsequently, inrushes of water from the floor did in fact occur when these zones were breached by excavation for development roadways, which confirmed the validity of our inference.

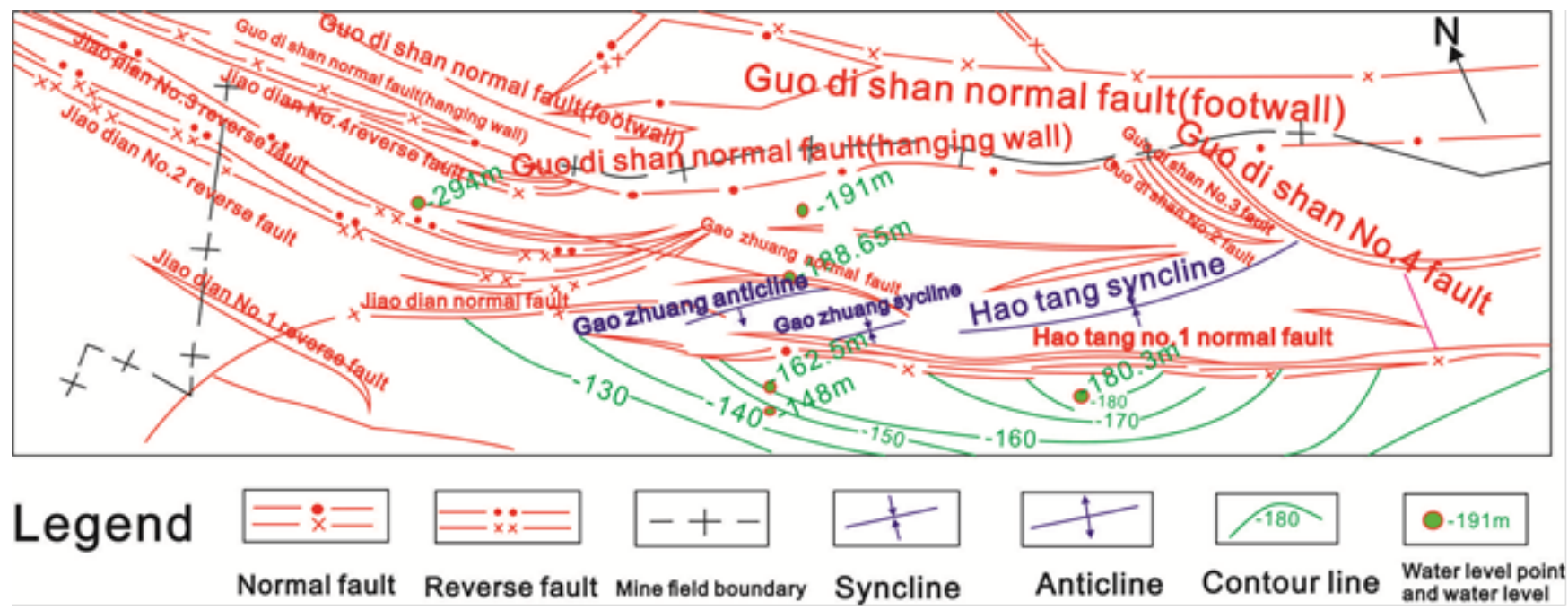

Fig. (6). Isoline map of water table levels in the CL aquifer. Source: [15]. 


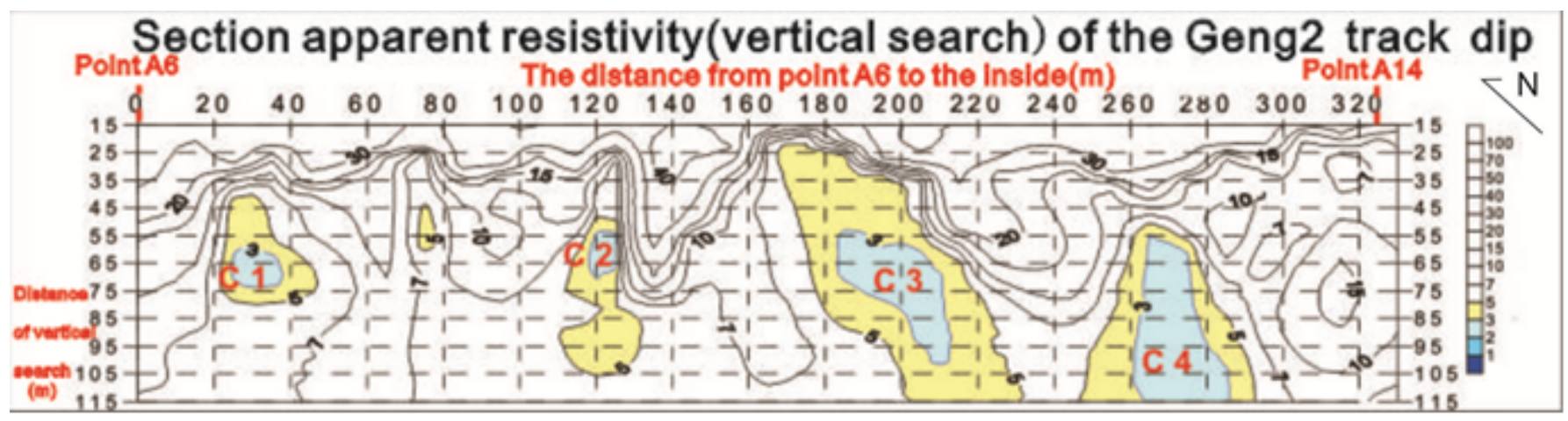

Fig. (7). Apparent resistivity section diagram for line 1. Source: [16].

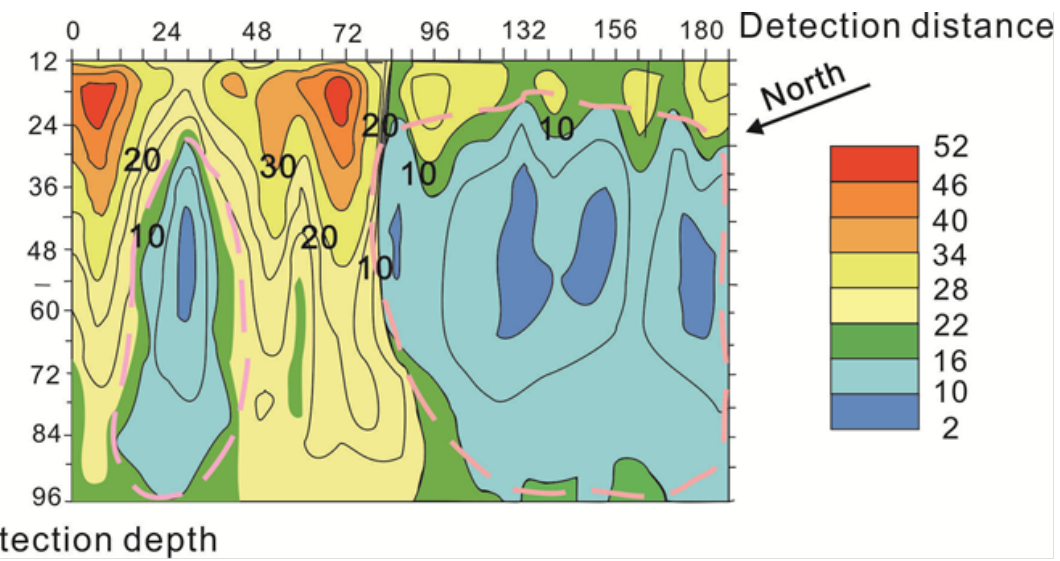

Fig. (8). Apparent resistivity section chart for line 2. Source: [16].

No apparent resistivity readings less than $2 \Omega \cdot \mathrm{m}$ were observed on line 1, and the water-bearing anomalies covered a smaller area than those on line 2 . These facts illustrate that the aquifer contains more water south of the fault than north of the fault. They also indirectly confirm that the CL aquifer groundwater contact isn't close both sides of the fault.

\section{DISCUSSION}

The study above indicate that the water-bearing capacity and water conductivity of the Haotang Fault is poor. Since that the $\mathrm{CL}$ water with great water-bearing capacity and water conductivity in south district could't cross the fault to north district. These make the weaker water-bearing capacity and smaller mine water inflow in north compared with south. It is because of the distance from $1_{5}$ coal mine floor to the $\mathrm{CL}$ is only $16.75 \mathrm{~m}$ and the water pressure of $1_{5}$ coal mine is about $0.8 \mathrm{MPa}$, the coal mining may easily lead the water inrush. Therefore, in the process of $1_{5}$ coal mining, we use geophysical exploration to confirm the CL water anomaly area, build the drillholes to get the water pressure, thickness of aquiclude and date of water-bearing capacity. According to these, that formulates the measure of water drainage hole, floor grouting, water transport system to make sure the safety mining of $1_{5}$ coal seam.

\section{CONCLUSION}

(1) Geological drill holes, roadway engineering and floor TEM data indicate that the Haotang Fault is subject to compressive or shear-compressive stresses. No karst fissures in the CL are developed in the fault zone in either the hanging wall or the footwall, as a result of which it has a relatively low water content.

(2) In zones remote from the Haotang Fault, the frequency of water inrushes, the hydrogeochemistry, the water level distribution, and the water content are all markedly different on either side of the fault, indicating that the CL hydraulic connection is not close and that water conductivity of the fault is particularly weak.

(3) Because of the water-bearing capacity and water conductivity of Haotang Fault is poor, the CL water with great water-bearing capacity and water conductivity in south district could't cross the Haotang Fault to north district. These make the weaker water-bearing capacity and smaller mine water inflow in north compared with south. While, in north district of the fault, it presents a smaller threat to mining in the $1_{5}$ coal seam.

\section{CONFLICT OF INTEREST}

The authors confirm that this article content has no conflicts of interest.

\section{ACKNOWLEDGEMENTS}

This work was financially supported by the National Natural Science Foundation of China (Grant 41272250 and 41302214) and Technological Innovation Team of colleges and universities in Henan Province (Grant 15IRTSTHN027). 


\section{REFERENCES}

[1] State Administration of Work Safety, State Administration of CoalMine Safety, Provisions for mine water prevention and control. China Coal Industry Publishing House, Xuzhou China.2009.9.

[2] X. Y. Wang, S. F. Li, and G. Q. Xu. Special hydrogeology. China Coal Industry Publishing House, Xuzhou China.2011.2.

[3] X. Y. Wang and Z. Y. Shan. Water controlling and the comprehensive utilization of water resources in Karst fissured coal mine. Coal Industry Press, Beijing China.2008.11.

[4] A.C. Cilliers, D. Nicholls, A.S.J. Helberg. "Fault detection and characterization in Pressurised Water Reactors using real-time simulations". Annals of Nuclear Energy, vol. 38, pp. 1196-1205, 2011.

[5] S. M. Awadh, K. K. Ali, and A. T. Alazzawi. "Geochemical exploration using surveys of spring water, hydrocarbon and gas seepage, and geobotany for determining the surface extension of Abu-Jir Fault Zone in Iraq: A new way for determining geometrical shapes of computational simulation models. Journal of Geochemical Exploration, 124, pp. 218-229, 2013.

[6] Dovzan, Dejan, L. vito, and H. Nadja. "Monitoring and sensor fault detection in a waste-water treatment process based on a fuzzy model". Electrotechnical Review, vol. 3, no. 78, pp. 142-246, 2011.

[7] Chen H.X., Chua Patrich S.K., and Lim G.H. "Fault degradation assessment of water hydraulic motor by impulse vibration signal with Wavelet Packet Analysis and Kolmogorov-Smirnov Test". Mechanical Systems and Signal Processing, vol. 7, no. 22, pp. 1670-1680, 2008.

[8] Huang P. H. and Chen J. S. "The chemical features of ground water and FDA model used to distinguish source of water burst in Jiaozuo mine area". Coal Geology and Exploration, vol. 39, no. 2, pp. $42-46,2011$

[9] Wang G. C., Tao S., and Shen Z. L. "The stochastic hydrogeochemistry model in karst groundwater system water-rock in Pingdingshan mine area". Hydrogeology and engineering geology, vol. 3, pp. 9-11, 2000.

[10] Li Q. F., Wang W. J., Zhu C. Q., and Peng W. Q.. "Analysis of fault water-inrush mechanism based on the principle of waterresistant key strata". China University of Mining and Technology, vol. 1, no. 3, pp. 87-90, 2009.

[11] Chen Z. H., Hu Z. P., Li H., Chen Q.F. "Fracture mechanical model and criteria of insidious fault water inrush in coal mines". China University of Mining and Technology, pp. 673-677, 2011.

[12] Bai H. B., Mao X. B., Wu Y., Chen Z. Q. "Research on waterreserved mining with high water pressure under large-scale thrustfault in Ordovician karst". Chinese Journal of Rock Mechanics and Engineering, vol. 2, no. 28, pp. 246-252, 2009.

[13] $\mathrm{Bu} \mathrm{W.} \mathrm{K.} \mathrm{"Research} \mathrm{on} \mathrm{effect} \mathrm{of} \mathrm{fault} \mathrm{dip} \mathrm{on} \mathrm{reversed} \mathrm{fault}$ activation and water inrush in coal floor". Electronic Journal of Geotechnical Engineering, vol. 18, pp. 2323-2336, 2013.

[14] Dong D. L., Wang H. Z., and Wu C.X. "Seepage characters of roof aquifers in faults and sliding structure and risk analysis of water inrush". Chinese Journal of Rock Mechanics and Engineering, vol. 2, no. 28, pp. 373-379, 2009.

[15] Pingdingshan Tian'an Mining Company Limited No. 7 Mine, Henan Polytechnic University. Hydrogeoloy exploration of Haotang high-angle normal fault. 2012.10.

[16] Henan Polytechnic University, Pingdingshan Tian'an Mining Company Limited No. 7 Mine. The research of water disaters comprehensive control and utilization technology in No. 7 Mine. 2012.11.

[17] China Pingmei Shenma Group (2013). “2012-2015” planning for coal mine limestone water control of Pingmei Shenma Group. China Coal Industry Publishing House, Xuzhou China.2013.2.

[18] Q. Wang, X. Y. Wang, and Q.L. Hou, 2015. Geothermal Water at a Coal Mine: From Risk to Resource. Mine Water and the Environment, DOI 10.1007/s10230-015-0352-6

(C) Wang et al.; Licensee Bentham Open.

This is an open access article licensed under the terms of the Creative Commons Attribution Non-Commercial License (http://creativecommons.org/licenses/ by-nc/3.0/) which permits unrestricted, non-commercial use, distribution and reproduction in any medium, provided the work is properly cited. 